\title{
Vertical Environmental Management: A Panacea to the Environmental Enforcement Gap in China?
}

\author{
MA Yun \\ Lecturer, Law School of China University of Political Science and Law \\ mayun@cupl.edu.cn
}

\begin{abstract}
After being proposed in 2015, environmental vertical management (VM) reform was hailed as being able to bridge the environmental law enforcement gap, because it helps in insulating environmental protection agencies from intervention by local governments, thus functioning to end local protectionism brought about by the traditional 'dual leadership' model. This article identifies how the ongoing reform process changes the institutional structure of environmental management, explains the reasons for initiating such a reform and analyses whether VM can be as effective as intended. It is concluded that promotion of an environmental vM reform reflects the vicissitudes of central government-local government relations in the environmental era. As a method to strengthen central oversight on local environmental performance, vM is far from the sole or the most cost-effective method to realize this goal. The environmental vM reform plan combines both centralization and decentralization approaches. The design of 'soft' (extension of reform below provincial level) and fragmented (selected monitoring and inspection) centralization may decrease the anticipated effectiveness of VM reform by moving local malfeasance from municipal and county levels to the provincial level ('provincial protectionism') and thus continuing to harm the integrity of environmental management. As a partial solution, vM reform needs to be supplemented with incentive and accountability mechanisms, and by more effective and professional enforcement activities at local levels.
\end{abstract}

* This article is financially supported by the fund of CUPL on scientific research for young scholars (中国政法大学校级青年科学研究项目资助) (project number:16ZGQ82004). 


\section{Keywords}

vertical management - environmental monitoring and inspection - dual leadership environmental law enforcement gap

\section{Introduction}

In 2015, the Fifth Plenary Session of the 18th Central Committee (CC) of the Communist Party of China (CPC) proposed to establish the so-called 'vertical management of environmental monitoring, inspection and law enforcement functions in environmental institutions below provincial levels' (省以下环保 机构监测监察执法垂直管理制度, hereafter the environmental VM system). ${ }^{1}$ Environmental management has long been governed by a so-called 'dual leadership' structure in China, which means that the environmental agency is led by both its superior agency and its territorial local government. There is a well-established causal link between this governing structure and the so-called local protectionism and enforcement gap at the local level. By shifting from 'dual leadership' to 'vertical management', the proposed VM reform is hailed as being able to enhance the authority, efficiency and efficacy of environmental enforcement by segregating environment-related authority from local interests. Though a guideline was recently released by the central authority, the details of how the proposed reform should proceed at local levels are not fully revealed. ${ }^{2}$ Nevertheless, this reform is deemed a fundamental change in the environmental governance structure and reflects the resolution of Chinese central authority to strengthen environmental law enforcement and realize good environmental governance.

The strategy of adopting VM systems has been used in China since the 1990s to correct local governments' over-zealous pursuit of economic growth, and to realize centralized control in taxation, financial systems and other fields. However, practices show that after decades of experience of VM reform, some of these reforms have stalled, or even regressed. The effectiveness of VM in realizing its anticipated goals has thereby been challenged.

This article aims to identify how the proposed vM reform will change the institutional structure of environmental management and law enforcement,

1 Recommendations of the CCCPC on Developing the 13th Five-Year Plan on National Economic and Social Development (中共中央关于制定国民经济和社会发展第十三个 五年规划的建议), 29 October 2015 .

2 For more discussion, see section 2.3 below. 
whether VM can be as effective as it is meant to be and if yes, to what extent. Three questions are examined: What is VM? Why do we need vM? Can vM be effective? Though broadly known as 'vM reform', the current reform in fact consists of a bundle of measures in which VM is partially applied to selective fields and within specific geographical ranges. In addition to adjusting the bureaucratic structure, the VM reform has had profound impacts on the overall scheme of environmental management in China. With regard to why vM reform is needed, the primary goal of bridging the enforcement gap and combatting local protectionism can be identified easily. Nevertheless, the reasons for the selection of monitoring, inspection and law enforcement and the choice of extension below provincial level in the current reform are more subtle and therefore need further examination. Last but not least, although the outcomes and consequences of this reform cannot yet be evaluated and assessed by empirical data, both theoretical studies and experiences of previous VM reforms may shed light on the pitfalls and challenges that the current reforms may encounter. As a method to strengthen central oversight on local environmental performance, VM is far from the sole or the most cost-effective method to realize this goal. The situation of soft and fragmented centralization observed in the current reform plan has potentially negative repercussions, including moving the concentration of local malfeasance from municipal and county level to the provincial level and thus continuing to cause harm to the integrity of environmental management. In its conclusion, the article makes some legal and policy recommendations to enhance the continued evolution of the current reform.

What is VM?

\section{1 'Dual Leadership'vs. VM}

China has established a dedicated bureaucracy extending from Beijing down through provinces, cities and counties to the level of village and township. Each level of government is similarly divided into different functional organs, with the functional organs ranging from central, ie, ministry, to local; jointly, they constitute a functional system (系统). Two lines of authority are therefore presented: the vertical line between central and local functional organs and the horizontal line between a functional organ and its territorial level of government. They are, in short, a vertical functional line and a horizontal geographic line. In Chinese, the vertical line is called tiao (条), and the horizontal line is called kuai (块).

Generally speaking, a functional organ is led by both its superior agency and the government within its geographical range at corresponding county, 
municipal, or provincial levels. This governing structure is termed 'dual leadership'(双重领导), which indicates a combination between tiao and kuai (条块 结合). Two types of leadership thereof are distinguished: one is called 'leadership relations' (领导关系) in which territorial local government controls the personnel, financial budget and material resources (人、财、物) of functional agencies, and the other is called 'professional relations' (业务关系) in which superior agencies supervise the daily affairs of agencies at lower levels in carrying out their defined functions. In the decentralized governance structure of China, leadership relations are normally superior to professional relations. Therefore, this system is also termed 'kuai-based management system' (属地 管理), which is the dominant mode of institutional structure in China. This is also the case for environmental management, which was clearly defined by the central authority in 1999: 'the governing structure of environmental management is dual leadership with dominance of local governments' leadership. ${ }^{3}$

In the field of environmental management, besides a dual leadership structure, the system combining 'integrated management' and 'separate management by relevant departments' (统一管理与分部门管理相结合) is adopted. ${ }^{4}$ Therefore, in addition to environmental protection agencies (EPBS) at all levels, other departments and agencies at corresponding levels of government, such as forestry and land administration, also shoulder the work of environmental management and supervision within their respective scopes of authority (see Figure 1).

In contrast to dual leadership, vM recasts the institutional structure in such a way that agencies are no longer beholden to the governments within their geographic ranges at corresponding county, municipal, or provincial levels (kuai). Rather, they are directly controlled by their functional superior agencies (tiao). Under VM, superior agencies not only supervise their subordinated agencies on professional affairs, but also take charge of personnel, budgetary and material resources that are formerly retained by local governments. The mechanics adopted to realize such a shift may vary in different fields. Generally, they include 'personnel/budgetary allocations (bianzhi), cadre recruitment and allocation (nomenklatura), and revenue collection, ${ }^{5}$ which are to be discussed in the following sections.

3 CCCPC and State Council, 中共中央国务院关于地方政府机构改革的意见 (Opinions of the CCCPC and the State Council on Institutional Reforms of Local Governments, Zhongfa [1999] No.2, 5 January 1999.

4 Article 10 of Environmental Protection Law, effective on 1 January 2015.

5 Andrew MERTHA, 'China's "Soft" Centralization: Shifting Tiao/Kuai Authority Relations', (2005) 184-1 The China Quarterly 791, 797. 


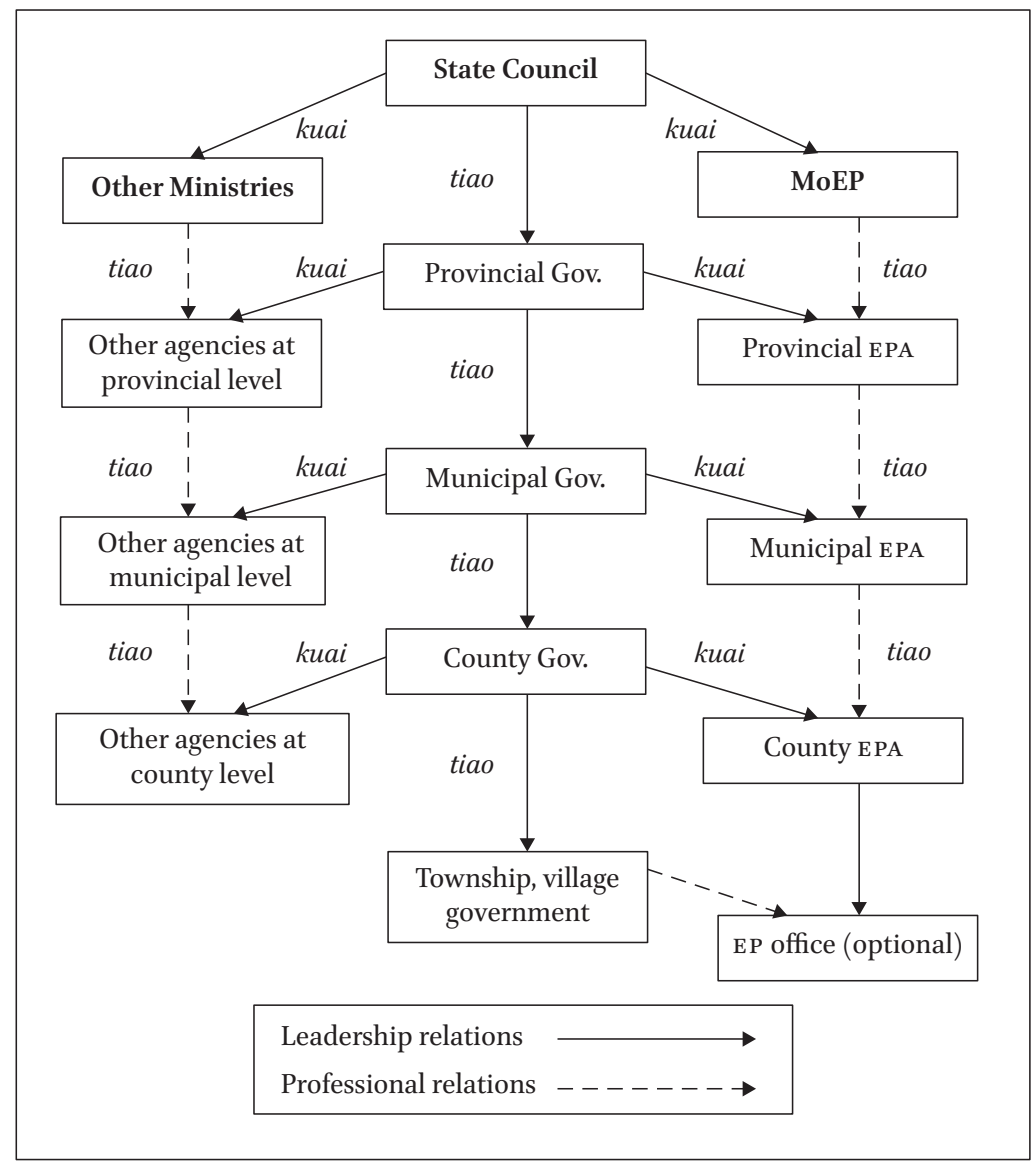

FIGURE 1 Institutional structure of environmental management in China.

2.2 VM Reforms in Other Fields

The VM system has been used in China since the 1990s to correct local governments' over-pursuit of economic growth, and realize centralized control in some key fields. ${ }^{6}$ For example, in 1995, the taxation sector initiated vM reform. In 1997, the central bank and the key four commercial banks began to adopt the vM system. The three supervisory boards established afterwards, ie, insurance, securities and bank, have adopted the same model. In late 1998, the VM structure was adopted in the administration of industry and commerce.

6 For generally discussions of vM reforms in China, see MERTHA, ibid; SHEN Ronghua, 分权背景下的政府垂直管理：模式和思路 (VM under decentralization: modes and ideas), (2009) 9 中国行政管理 (Chinese Public Administration) 38,41. 
In 1999, the sector of quality and technology supervision followed a similar path. The VM system was strengthened from the year 2000 onwards. In 2000, the Pharmaceutical Supervision Management Bureau began to carry out the centralized management plan on drug supervision. In 2004, the statistical bureau began to adopt VM for survey teams sent out to lower levels of government. In 2005, the State Coal Industry Supervision Bureau adopted a VM structure. In 2006, the General State Land Inspection Office was established under the Ministry of Land and Resources, which supervises the 9 state land inspection bureaus in Beijing, Shenyang, Shanghai and other 6 cities.

Either of two modes of VM is generally adopted: one is 'VM throughout all levels of government', such as banking and customs, and the other is 'vM below provincial levels', such as industry and commerce administration, and quality and technology supervision.

\subsection{Environmental VM Reform}

The establishment of a VM system in environmental management has been advocated for decades in China. After the proposal was released by the CPC in 2015, it was placed on the priority list of environmental system reform. An ad hoc office in charge of environmental VM reform was established within the Ministry of Environment Protection in early 2016. In July 2016, the Leading Group of Comprehensively Deepening the Reform of the Communist Party of China (Reform Group) issued Guidelines on the Pilot Program of Vertical Management Reform of Environmental Monitoring, Inspection and Law Enforcement below the Provincial Level (关于省以下环保机构监测监察执 法垂直管理制度改革试点工作的指导意见, hereafter 'Guidelines'), which were released to public access in September 2016. These Guidelines sketch the frame of the proposed reform and set a timespan for its accomplishment, which is one year for the pilot reforms in selected 12 provinces $^{7}$ and four years for the nationwide reform. At the time of writing, the first batch of pilot reforms of Hebei province and Chongqing municipality had been publicly approved and released. ${ }^{8}$

7 Hebei, Shanghai, Jiangsu, Fujian, Shandong, Henan, Hubei, Guangdong, Chongqing, Guizhou, Shaanxi and Qinghai (12 provinces in total) have been approved for the candidature of pilot VM reforms.

8 JIANG Mengwei, 我国首批环保垂改试点方案获批 (The first batch of environmental vM reform plans approved), in 北京商报 (Beijing Business Today), 29 November $2016<$ http:// finance.sina.com.cn/roll/2016-11-29/doc-ifxyawxa3095003.shtml> accessed 26 December 2016. 
Before the central authority took the final step, a number of provinces and cities initiated pilot VM reforms on a small scale. In 2003, Xuzhou, in Jiangsu province, took the lead in initiating VM of environmental management within its jurisdiction. Statistics have shown that, by 2011 (the latest statistics available), there were more than 200 grassroots EPBs in Hainan, Jiangsu, Zhejiang and other provinces that have adopted environmental vM reforms. ${ }^{9}$ Most of these pilot reforms took place below the municipal level. ${ }^{10}$ The current environmental VM reform launched by the central authority can be deemed an extension of the previous pilot reforms that were initiated in a bottomup manner.

It is worth noting that, although called 'vM reform', only selected fields of environmental management are chosen for vertical management, namely environmental monitoring (EM), environmental inspection (EI) and law enforcement. Nevertheless, as shown in the Guidelines, the ongoing reform consists of a bundle of reform measures associated with VM on EM and EI, which sheds light on the overall environmental governing structure in China. Specifically, the reform plan consists of 3 key parts:

1. Institutional structure: municipal EPBs shall be under dual leadership in which provincial EPBS play a dominant role while territorial governments play an ancillary role; EPBs at the county level will be no longer an authorized agency per se, but a branch dispatched and directly controlled by municipal EPBs;

2. VM of EM and EI: the functions of EM and EI previously associated with municipal and county EPBs shall be centralized at the provincial level;

3. Capacity building for law enforcement at and below municipal level, including provision of equipment and professional training, integration into formal bureaucracy and legal empowerment, etc.

\subsubsection{Reform of Institutional Structure}

Unlike previous VM reforms in other fields in which the target agencies are no longer components of local governments, the status of municipal EPBs as constituent departments of municipal governments remains unchanged. The 'dual leadership' structure for municipal EPBs is retained, with a shift from

LI Xuan and SHEN Xiaoyue, 我国地方环保垂直管理体制改革的经验与启示 (Experiences and lessons from local institutional reforms of environmental vertical management), (2011) 21 环境保护 (Environmental Protection) 36.

10 JU Changhua, 环境保护垂直管理的探讨 (Analysis of environmental vertical management), (2013) 41-8 环境保护 (Environmental Protection) 56. 
a kuai-based to a tiao-based management system, ie, provincial EPBs play a dominant role in this dual leadership, compared with the role played by local governments.

Such a shift is mainly accomplished through the means of cadre recruitment and allocation, termed 'nomenklatura' in the literature. ${ }^{11} \mathrm{~A}$ fundamental principle of 'placing cadres under Party supervision' (党管干部) has been adhered to by the CPC. Under a kuai-based management system, the leaders of municipal EPBS are generally chosen and surveyed (考察) by CPC Organization Departments (组织部) at municipal level, and subsequently nominated by the municipal CPC committee (党委).

In the proposed reform, according to the Guidelines, the leading Party members' group (党组) ${ }^{12}$ at provincial EPBs shall nominate the director and vice-director of municipal EPBs, consult with municipal CPC committees and submit its nomination decision to the municipal CPC committee and municipal government. The directors of municipal EPBs shall be appointed and dismissed by municipal people's congress, while the secretary, deputy secretary and other members of the leading Party members' group at municipal EPBS shall be appointed and dismissed by the leading Party members' group at provincial EPBS.

In other words, after a shift from a kuai-based to a tiao-based management system, the power to nominate leaders of municipal E PBs (cadres) is retained by the Party apparatus within the environmental bureaucracy, ie, the leading Party members' group at provincial levels, instead of local CPC Organization Departments that are deemed to be more closely connected to local CPC committees and local governments.

Similarly, cadre appointment at county level is accordingly transformed. Since EPBs at county level will become a branch of municipal EPBs, the leaders of a county EPA shall be appointed and dismissed by municipal EPBS, instead of the county CPC committee before the reform. In this way, at both municipal and county levels, the power to appoint cadres is retained by the environmental bureaucracy.

\subsubsection{Reform of Environmental Monitoring}

Before looking into relevant reform measures, it is necessary to first define the authority of EM. According to the Measures for the Administration of

\footnotetext{
11 For discussions of China's nomeklatura system, see generally John BURNS, 'China's nomeklatura system', (1986) 36 Problems of Communism 36.

12 The leading Party members' group is formed in the leading body of a central or local state organ and plays the role of the core of leadership. One of its core tasks is cadre appointment and allocation. See the Constitution of CPC, Article 46.
} 
Environmental Monitoring of 2007, ${ }^{13}$ 'environmental monitoring' refers to the following types of activities:

1. Environmental quality monitoring;

2. Supervisory monitoring of pollution sources;

3. Emergency response monitoring of environmental pollution; and

4. Other environmental monitoring activities for the provision of monitoring data for environmental management activities such as investigation and assessment of environmental conditions (Article 2).

With regard to the institutional structure before the current reform, EPBs at and above the county level are responsible for uniform supervision and administration of EM within their regions. EM bodies are affiliated with EPBS, and are accordingly divided into four levels, ie, state, provincial, municipal and county levels. Similar to EPBs before the VM reform, EM bodies are under dual leadership. On the one hand, they are responsible to the EPBs at corresponding levels, and on the other hand supervised and guided by the EM bodies at higher levels on professional matters. ${ }^{14}$

In the current reform process, the Guidelines distinguish between environmental quality monitoring and environmental law enforcement monitoring, followed by relevant reform measures. With regard to the former, the authority of environmental quality monitoring, investigation, assessment and appraisal is centralized at provincial EPB level. Municipal EM bodies become branches directly controlled by provincial EPBS, which means that 1 ) the personnel and budgets of municipal EM bodies are administered by provincial EPBs; and 2) the leaders of those bodies are appointed and dismissed by provincial ЕРвS.

With regard to environmental law enforcement monitoring, in contrast, EM bodies at county level mainly take charge of monitoring of law enforcement, such as monitoring of pollution sources. These EM bodies at county level are directly led by county EPBs, ie, the branches of municipal EPBs, and their personnel and budgets are administered by municipal EPBs. In summary, the authorities of law enforcement monitoring and environmental quality monitoring are respectively centralized at municipal and provincial levels.

13 State Environmental Protection Administration (SEPA, now Ministry of Environment Protection), 环境监测管理办法 (Measures for the Administration of Environmental Monitoring), Order No.39 of SEPA, effective on 1 Sept. 2007.

14 Article 5 of the Measures of Environmental Inspection; Article 11 of to the Measures for the Administration of Environmental Monitoring. 


\subsubsection{Reform of Inspection and Law Enforcement}

The claimed scope of environmental VM reform covers 'inspection and law enforcement' (监察执法); in Chinese, these two terms at first sight seem to be synonymous. However, according to the Guidelines, reform measures on inspection and law enforcement are separately addressed and the term 'inspection' is newly defined. Since there is no clear definition of inspection provided in law, to avoid confusion, it is necessary to distinguish these two terms.

There is only one law (法律), issued by the National People's Congress and its Standing Committee focused on 'inspection', namely the Law on Administrative Inspection (行政监察法). ${ }^{15}$ Inspection therein is generally understood as supervision of compliance with laws, regulations and administrative disciplines by administrative organs and civil servants. In contrast, based on the reading of the Environmental Inspection Measures (环境监察 办法), 'environmental inspection' (EI) refers to 'administrative law enforcement activities carried out by relevant environmental protection authorities in accordance with the laws, regulations, rules and other normative documents on environmental protection.' ${ }^{16}$ In this sense, environmental inspection is synonymous with environmental law enforcement.

EI bodies that carry out EI functions are divided into four levels, which are EI Headquarters (环境监察总队) at provincial levels, EI Divisions (环境监 察支队) at prefectural levels, EI Team (环境监察大队) at county levels and EI Squad/EI Office (环境监察中队/环境监察所) at township levels. Similar with EM bodies, EI bodies are also subordinated to EPBS and under dual leadership. As a whole, EI bodies constitute the main environmental law enforcement forces. They are charged with comprehensive and miscellaneous tasks of law enforcement activities, as enumerated in Article 6 of the Measures of Environmental Inspection. In short, they mainly take charge of:

1. Supervision of the implementation of laws and regulations;

2. On-site supervision and inspection over pollution sources, nature conservation etc.;

3. Registration, verification and collection of pollution discharge fees;

4. Investigation on environmental law violations;

5. Receiving complaints and dispute resolution.

15 Issued by the Standing Committee of the National People's Congress in 1997 and amended in 2010.

16 Article 2, issued by the Ministry of Environment Protection on 1 September 2012. 
Nevertheless, the scope of the tasks that EI bodies carry out cannot be equated with the definition of 'inspection' per se. This can be seen from the scope of EI exemplified in the Guidelines. According to the Guidelines, the authority of EI at both municipal and county levels shall be centralized to provincial EPBs. Provincial EPBs may dispatch and empower officers at municipal and county levels to carry out functions of EI. Once authorized by provincial governments, provincial EPBS are empowered to check and supervise the enforcement of environmental laws, regulations, standards, policies and plans by municipal and county governments and relevant departments. They can also supervise and check the implementation of the mechanism of 'dual responsibilities for one position' (一岗双责) ${ }^{17}$ and other accountability mechanisms, and report to provincial CPC committees and governments. The above-mentioned reform measures indicate that EI mainly refers to the top-down supervision from a higher level of authority to one at lower levels. This function defined by the Guidelines is hardly formalized and institutionalized under the current structure. Accordingly, the Guidelines propose to establish the so-called environmental ombudsman (环境监察专员) system to formalize the function of EI. ${ }^{18}$

In contrast, environmental inspection reform on law enforcement reflects the idea of decentralization and is confined within the municipal and county levels. It generally refers to law enforcement activities concerning enterprises. The Guidelines stipulate that municipal E PBs shall uniformly manage law enforcement forces at county levels within their jurisdictions by administering their personnel and budgets. The 'law enforcement forces' referred to herein generally cover officers of EPBS and those EI bodies at different levels discussed above.

This distinction between inspection and law enforcement may distort the normative definition of EI, as previously discussed, although a clear legal definition of EI is absent in law. The confusing relationship between EI and law enforcement is highlighted by Wu Shunze, the Vice Director of Chinese Academy for Environmental Planning affiliated to the Ministry of Environment Protection, in a newspaper interview. He said new EI and old EI needs to be distinguished after the VM reform. The former refers to 'supervision of

\footnotetext{
17 See section 4.2 below.

18 The reform plan of Hebei Province has explicitly established the environmental ombudsman system. Cross-regional ombudsman offices are set, which are affiliated to provincial EPA and allocated to cities. See Plan of Hebei Province in Implementing Environmental vM Reform in Monitoring, Inspection and Law Enforcement (河北省环保机构监测监 察执法垂直管理制度改革实施方案), 17 December 2016 <http://he.people.com.cn/ n2/2016/1220/c192235-29486075.html> accessed 26 December 2016.
} 
governments' (督政), ie, supervision and inspection of local governments' environmental performance by provincial organs. The latter refers to 'supervision of enterprises'(督企), ie law enforcement activities carried out by E I bodies at municipal and county levels concerning local polluting enterprises. ${ }^{19}$ In this sense, EI and law enforcement might have contextual implications and therefore may be interchangeably used in the following discussions.

\subsubsection{Summary}

Based on the discussion above, Table 1 summarizes the main contents and the mechanics adopted by the current reform process.

The following figures depict the institutional structural change before and after the VM reform. In Figure 2, it is noted that under the current governance structure, unlike administrative organs in which the staff are civil servants; EM and EI bodies are not officially part of the bureaucracy. Instead, they are 'public institutions' (事业单位) and their working staff are not identified as civil

TABLE 1 Contents and mechanics of environmental VM reform

\begin{tabular}{llll}
\hline Areas & & Proposed reform & Mechanics \\
\hline $\begin{array}{l}\text { Institutional } \\
\text { structure }\end{array}$ & Municipal level & $\begin{array}{l}\text { Kuai-based to tiao-based } \\
\text { dual leadership } \\
\text { Direct and complete } \\
\text { control of county EPBs by }\end{array}$ & $\begin{array}{l}\text { Cadre appointment and } \\
\text { allocation }\end{array}$ \\
& County level & municipal EPBs & \\
EM & Environmental quality & Centralized to provincial & Personnel/budgetary \\
& monitoring & EPBS & allocations (bianzhi); \\
& Law enforcement & Centralized to municipal & Cadre recruitment and \\
& monitoring & EPBs & allocation \\
EI & New EI (supervision on & Centralized to provincial & Ombudsman (in progress) \\
& governments) & EPBs & \\
& Old EI (supervision & Centralized to municipal & Personnel/budgetary \\
& on enterprises) / law & EPBs & allocations (bianzhi) \\
& enforcement & &
\end{tabular}

19 WANG Jingzai, 中国省级以下环保机构垂直管理 直指㽽疾 (Environmental vM reform below provincial level targeting chronic illness), in 法治周末 (Legal Weekend), 28 September 2016 <http://news.hexun.com/2016-09-28/18622356o.html> accessed 26 December 2016. 
servants. ${ }^{20}$ While they are still paid by the government, their salary and social benefits are at a lower level, and they have fewer promotion opportunities. They generally work on a contractual basis. These public institutions are entrusted (行政委托) by EPBs to conduct EM and EI. Such staff are therefore subject to change and their availability is unstable. Even worse, in practice, some local EPBs are also public institutions, which should have been administrative organs according to relevant organic law, and are therefore afflicted with similar problems. ${ }^{21}$

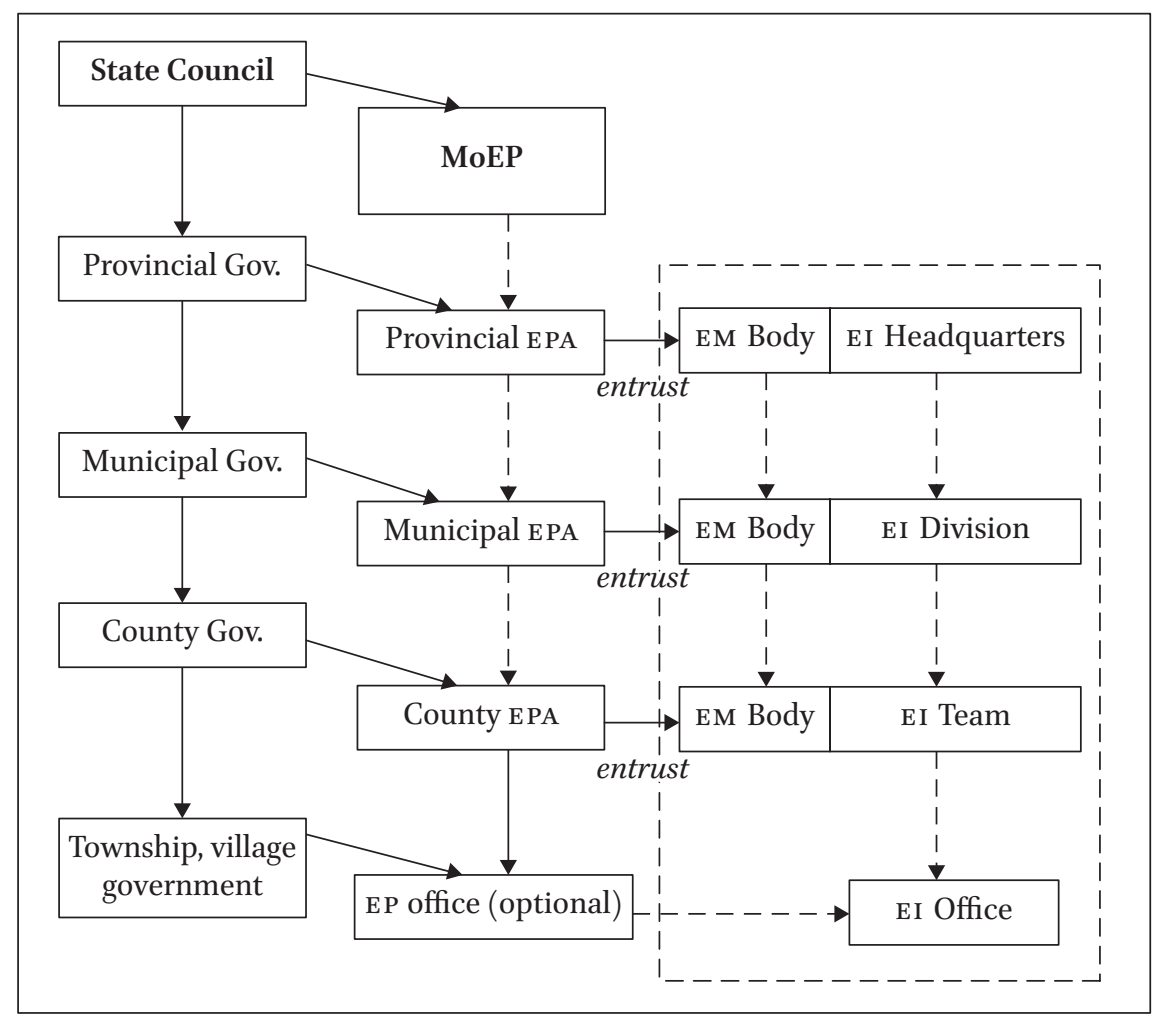

FIGURE 2 Institutional structure before VM reform.

20 Ziran BAO, 'Reflections on China's environmental protection administration system', ECOJESUIT, 31 December $2012<$ http://www.ecojesuit.com/reflections-on-chinasenvironmental-protection-administration-system/4617/> accessed 26 December 2016;

21 There are currently 182 local E PBs that are administrative organs, and more than 100 local EPBs that are public institutions. See YUE Jiachen, 环保监测监察系统垂直改革方案 露出 ‘庐山真面” (The reform plan of environmental VM reform on EM and EI is finally revealed), in 南方周末 (Southern Weekly), 22 September 2016 <http://www.infzm.com/ content/119886> accessed 26 December 2016. 
Ideally, after the reform, as depicted in Figure 3 below, law enforcement forces, including both EPBS and EI bodies that operate outside the formal bureaucracy, would be transferred and integrated into administrative organs, though much leeway and discretion is conferred upon pilot provinces to make locally specific reform plans. The Guidelines generally stipulate a precondition for such a transfer, which is within the current authorized quota of administrative organs and personnel. The aim of this requirement is to remain consistent with the goal of simplifying and downsizing administration promoted in the parallel governmental reform. How local law enforcement bodies may be restructured awaits further development.

\section{$2.4 \quad V M$ vs. Environmental Supervision System}

It is worth noting that in addition to promoting the VM reform, another remarkable initiative was recently launched at the central level, namely 'environmental supervision' (督察 ducha), an ad hoc mechanism originally established in 2006. Both environmental supervision and vM reform are mechanisms to

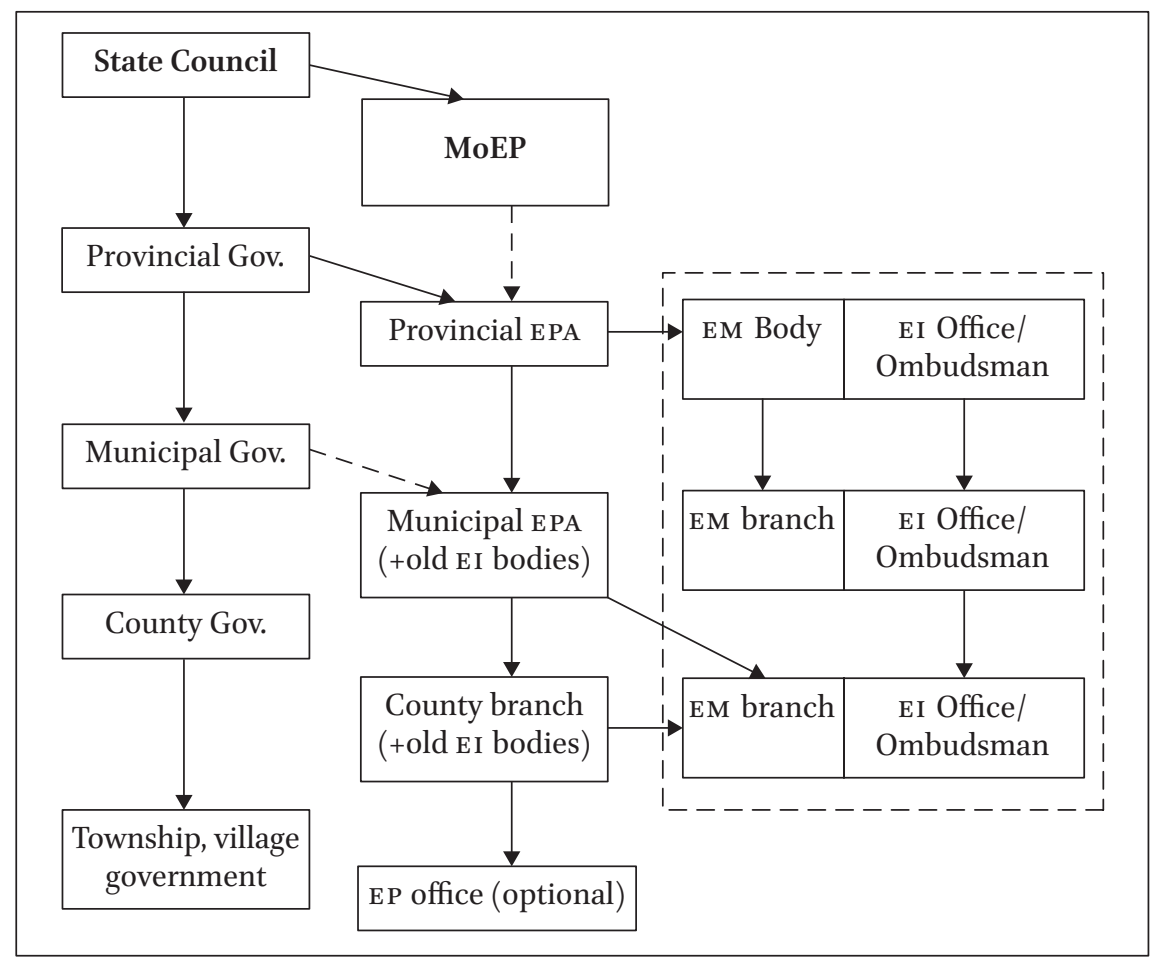

FIGURE 3 Institutional structure after VM reform. 
realize more intensified central control over environmental management, while the former is also deemed the prelude of the current vM reform.

In 2006, the then-SEPA (国家环保总局) (now the Ministry of Environment Protection) established five Environmental Supervision Centres in eastern China, southern China, northwest, southwest and northeast regions, and six Nuclear Radiation Safety Supervision Centres in Shanghai, Guangdong, Sichuan, northern China, and the northeastern and northwestern regions. These centres supervise environmental law enforcement by local governments on behalf of the central authority. This mechanism was further consolidated and elaborated in 2015 when the Reform Group issued a special plan for it. ${ }^{22}$

Starting from July 2016, the new wave of environmental supervision was initiated. The Central Group of Environmental Protection Supervision (CGEPS, 中央环保督查组) is composed of high rank officials at the central level, and is compared to the notion of 'imperial envoy' (环保钦差). Their appearance has quickly drawn a good deal of public attention. Since July 12, the first batch of CGEPS gradually entered and stayed in eight provinces to conduct ad hoc environmental supervision for periods up to one month. Their targets are cadres of provincial CPC committees and governments, the top leaders of Chinese local bureaucracies. The second batch was sent out in November to conduct similar supervision.

Their achievements are impressive. By 30 December 2016, the CGEPS had concluded 15,396 cases of environment-related whistle-blowing in 16 provinces, ordered 10,512 enterprises to make rectification, dealt with 5,779 cases of administrative punishment with the total amount of 243 million RMB of fines, made appointment with and interviewed (约谈) 4,066 persons in which 2,682 were held accountable either according to the CPC disciplines or relevant civil servant laws. ${ }^{23}$

Both VM reform and environmental supervision reflect a tendency to strengthen central control and oversight over the conduct of local governments. In 2015, when the VM reform was proposed by the CPC, the mechanism of environmental supervision was also promoted as a parallel mechanism of reforming environmental governance. In fact, the promotion of new EI in the

22 Reform Group, Plan of Environmental Protection Supervision (for trial implementation) (环境保护督察方案 (试行)), not publicly available.

23 Ministry of Environmental Protection, 第二批中央环境保护督察进驻结束 要求 各地继续做好边督边改工作 (Supervision by the second batch of CEGPS is finished) 31 December 2016 <http://www.mep.gov.cn/gkml/hbb/qt/201612/t20161231_393731.htm> accessed 28 February 2017. 
VM reform discussed earlier can be deemed an extension of the environmental supervision mechanism below provincial levels.

\section{$3 \quad$ Why Environmental vM Reform?}

In this section, the reasons for promoting comprehensive VM reform, especially the anticipated goals to bridge the enforcement gap and combat against local protectionism, are analysed. Further, the reasons for the choice of particular fields of environmental management, ie, EM, EI and law enforcement, and the choice of the geographical range, ie, below provincial level, in the current reform are presented.

\subsection{Enforcement Gap, Local Protectionism and VM Reform}

There are several goals that the VM reforms aim to accomplish. The most crucial one is to strengthen the authority of environmental law enforcement by decreasing inappropriate intervention from local governments. The lax enforcement of environmental laws and regulations in China is broadly recognized in existing literature, in which local protectionism has long been identified as one of the most crucial reasons for the enforcement gap. ${ }^{24}$ Stefanie Beyer notes that 'enforcement tensions between the centre and the periphery [are] a result of decentralization and growing local protectionism, [and are] major obstacles to the implementation process. ${ }^{25}$ Questions arise as why there is local protectionism and how the bureaucratic restructuring by VM may play a role in combating it.

Ever since China's opening-up reform, aiming at promoting local governments' initiative and creativity, decentralization has become a major theme

24 MA Xiaoying and Leonard ORTOLANO, Environmental Regulation in China, Institutions, Enforcement, and Compliance (Rowman and Littlefield Publishers, 200o); WANG Canfa, 'Chinese Environmental Law Enforcement: Current Deficiencies and Suggested Reforms', 2(2006) Vermont Journal of Environmental Law, p.171; Benjamin VAN ROOIJ, Regulating Land and Pollution in China, Lawmaking, Compliance, and Enforcement; Theory and Cases (Leiden: Leiden University Press, 2006) 264; MA Yun, Conservation and Recreation in Protected Areas: A Comparative Legal Analysis of Environmental Conflict Resolution in the United States and China (Routledge, 2016) 226-229. For most recent literature, see Benjamin VAN ROOIJ et al., 'Pollution Enforcement in China: Understanding National and Regional Variation', in Eva STERNFELD (ed.), Routledge Handbook of Environmental Policy in China (London: Routledge, 2017).

25 Stefanie BEYER, 'Environmental Law and Policy in the People's Republic of China', (1988) 47-1 Chinese Journal of International Law 185. 
in reforming China's governing structure. Consequently, the horizontal line of power at the local level is strengthened while the vertical line within a functional system has been weakened. Local governments obtained more freedom and control in personnel appointment, materials and budgets. It is widely believed that decentralization in China in the post-Mao era has resulted in competition between local governments, which is vital to the growth of the Chinese economy. ${ }^{26}$ However, this structure has its consequences, an explicit one of which is local protectionism, ie, adaptation and mutation of national laws, regulations and policies to suit local interests.

Local governments are deemed arch culprits for the increasing environmental problems. Empirical examples are rife. In 2006, the pollution from a smelting plant in Hui County, Gansu Province resulted in serious lead poisoning affecting; 2,00o villagers. ${ }^{27}$ In this shocking incident, local government played a dishonourable role by labelling the enterprise a 'key protected enterprise' and setting the so-called 'quiet production day'. This refers the situation where no agency or officer is allowed to conduct any type of on-site inspection without a special permit from local government. Under these circumstances, local EPBS play a passive and humble role in comparison with the powerful role played by local governments.

Under the dual leadership system, the influence exerted by personnel appointment and budget allocation are comparatively heavier than the ones exerted by supervision of professional affairs. The salaries and subsidies of local E PBS are provided by local governments, whose finances largely rely upon polluting enterprises that play a crucial role in providing job opportunities and increasing tax revenues. Therefore, local EPBs might be compelled or inclined to follow instructions from local governments to favour economic growth in case of inconsistency between central and local policies in environmental protection.

The solutions to cope with this mainly comprise two aspects: the first is to include environmental protection in the list of indicators to assess local officials' performance during their terms, which was formerly dominated by economic indicators, such as GDP; and the second is to re-centralize powers from

26 Gabriella MONTINOLA, Yingyi QIAN and Barry R. WEINGAST, 'Federalism, Chinese Style: The Political Basis for Economic Success in China', (1995)48-1 World Politics 50.

27 WANG Yanming and WANG Heng, 甘肃徽县: “重点保护” 在保护什么 (Gansu Hui County: what is 'key protection' protecting?), in新华每日电讯 (Xinhua Daily Telegraph), 16 September 2006 <http://news.xinhuanet.com/mrdx/2006-o9/16/content_5097864. htm $>$ accessed 26 December 2016. 
local governments' hands to higher levels and shift the authority relationship from kuai to tiao. Among others, vM reform is a key step towards the shift.

\subsection{Choice of Fields: EM, EI and Law Enforcement}

As discussed earlier, the proposed VM reform does not refer to complete VM of EPBS, but only the functions of EM and EI associated with EPBS. In reality, the structure of dual leadership is retained at both provincial and municipal levels, and law enforcement is further decentralized to municipal and county levels. The reasons behind such a choice are mainly as follows:

1. The situation in EM, EI and law enforcement is most problematic.

First, the accuracy and authenticity of environmental monitoring data has long been subject to question. In 2015, 2,658 cases of fabrication of monitoring data were reported and 78 cases were filed in 17 provinces and cities. ${ }^{28}$ The Environmental Protection Law of 2015 (EPL) prescribes that monitoring bodies shall be responsible for the truth and accuracy of monitoring data (Article 17) and stipulates the responsibility of polluting enterprises and environmental bureaucracy on 'altering or forging monitoring data' (Articles 63 and 68).

With regard to EI and law enforcement, there are two most significant problems. The first is rent seeking and corruption. According to the Statistical and Analytical Report of Cases in Violation of Laws and Discipline among Officers in the Nationwide Environmental Functional System between 2008 and 2010, $30.6 \%$ of the investigated officers are working in the field of EI. Their misconduct included failure to carry out supervisory duties seriously and acceptance of bribes by taking advantage of their authority over inspections. ${ }^{29}$

The second problem is a serious mismatch between the scale of the tasks conferred upon EI bodies (in the sense of 'old EI') and flawed capacity building. The latest available statistics, up to 2014, recorded that there were 80,000 E I officers overburdened with tasks of on-site inspection of 1.5 million enterprises, on-site investigations resulting from more than 1 million complaints and letters and visits, registration and collection of pollution discharge fees

28 CUI Jing etc., 1 年 “揪出” 2000 多起环境监测数据造假案 (More than 2,000 cases of environmental monitoring data fabrication were uncovered within one year), in 新华每 日电讯 (Xinhua Daily Telegraph), 15 April 2016 <http://news.xinhuanet.com/mrdx/201604/15/c_135281093.htm > accessed 26 December 2016.

29 CHEN Lei et al., 省以下环保监测执法将垂直管理 (Environmental vM reform in EM and EI), in 南方都市报 (Southern Metropolis Daily), 30 October 2015 <http://epaper .oeeee.com/epaper/A/html/2015-10/30/content_6773.htm> accessed 26 December 2016. 
of 500,000 enterprises, investigation and evidence collection of 140,000 administrative penalty cases, on-site verification of online data monitoring of 100,000 enterprises under state surveillance and other affairs relating to ecological protection and mediation of environmental disputes. ${ }^{30}$ On any analysis, these responsibilities appear to be far beyond what might be considered reasonable. Furthermore, local environmental law enforcement officers are not well equipped and trained. For example, in a southern province, there are, on average, 41.7 law enforcement officers in municipalities and only 16.3 in counties and districts. Over a third of law enforcement vehicles are placed at provincial and municipal levels with only 2 vehicles on average in districts and counties, and 21 districts and counties without any vehicles. ${ }^{31}$ Even worse, the status of 'public institution' of EI bodies decreases their authority in enforcing the law. ${ }^{32}$ Law enforcement officers are not taken seriously: refusal of law enforcement by enterprises or assault and battery of officers are frequently exposed in the media. ${ }^{33}$

2. Resistance from local governments impedes the overall restructuring of bureaucracy.

VM reform indicates centralization of power by provincial bureaucracies from those below, such as decision-making over the number of personnel appointments and budgetary outlays. Since local governments fear that local power may be fragmented and weakened, it is natural that the VM reform may en-

30 LIU Xiaoxing and YAO Yinle, 环境监管: 小马怎能拉动大车? 监管力量与监管任务 不相匹配 (Environmental supervision and management: how could a pony be capable of pulling a huge cart? Mismatch between capacity building and inspection tasks), in 中国环境报 (China Environment News), 24 October 2014 <http://news.cenews.com.cn/ html/2014-10/24/content_19533.htm> accessed 26 December 2016.

31 WANG Shuyi and ZHENG Zewen, 论绿色发展理念下环境执法垂直管理体制的改 革与构建 (Study on the reform and construction of environmental law enforcement vertical management system under the green development concept, (2015)43-23 环境保护 (Environmental Protection) 12.

32 LIU Jing, 对省以下环保机构监测监察执法垂直管理制度的思考 (Studies on the vertical management of environmental monitoring, inspection and law enforcement bodies below provincial levels), (2016) 16 环球市场信息导报 (Global Market Information Guide) 21.

33 For example, in November 2015, a female law enforcement officer, Shen, was seriously battered by the leader of an enterprise in Nantong city, Jiangsu province during her routine inspection on the enterprise's enforcement of environmental law. See LIANG Yuejing, 江苏一女环保执法员遭污染企业负责人殴打, 打人者被拘七天 (A female environmental law enforcement officer was assaulted by a polluting enterprise's leader; the offender was detained for 7 days), in 澎看新闻 (The Paper), 18 November 2015 <http:// www.thepaper.cn/newsDetail_forward_1398352> accessed 26 December 2016. 
counter resistance from local governments. ${ }^{34}$ Difficulties thus clearly exist in promoting VM in all aspects of environmental management. This partial reform may result in fragmentation in environmental management, which is discussed below.

3. Reform plausible due to relative independence of EM and EI bodies as 'public institutions'

As indicated earlier, EM and EI bodies are public institutions, which are not part of formal bureaucracy, and thus they are comparatively independent. It is easier to restructure these institutions, borne out of previous networks of vested interests, than fundamentally changing the internal structure of bureaucracies.

\subsection{Choice of Geographical Range: Below Provincial Level}

The current VM reform is confined to the provincial level. Similar to the choice of EM and EI for VM, the decision to promote the reform below provincial level is also a kind of compromise. The difficulties in proceeding with VM reform at all levels of government can be formidable. Considering the diversities and disparities from one region to another, a 'one-size-fits-all' approach may not work in China. Moreover, geographical distance between the centre and localities may increase the costs of generating information, communications and supervision. Promotion of reforms in a step-by-step manner is the common trajectory that China has followed in nearly every field of policy-making and implementation since the opening-up reforms of the $1980 \mathrm{os}$. This is also consistent with several previous VM reforms in other sectors that have centralized a growing number of regulatory bureaucracies up to the provincial level, such as administration of industry and commerce. Mertha terms this phenomenon 'soft' centralization, which is 'a natural compromise in which Beijing can rein in local excesses, but provincial control allows for a degree of sensitivity for local conditions in the implementation of national policy'. ${ }^{35}$

Dual leadership and vM reflect the two dominant governing structures in China. Generally speaking, vM reforms are based on the assumption that VM is

34 MA Tianjie, 环保 “垂直管理” 背后的博弯 (Game behind environmental VM), (2015) 12 环境教育 (Environmental Education) 19.

35 MERTHA ( $\left.\mathrm{n}_{5}\right) 804$. 
better than dual leadership because it may relieve agencies from intervention by local governments and therefore can do a better job; but is this true? The practices of existing VM reforms in other sectors show that, after decades of VM reforms in the fields of quality and technology supervision and industry and commerce administration, the reforms have stalled, or have gone backwards. By 2009, when the Law on Food Safety was issued, the vM systems in the two sectors were converted back to dual leadership. Furthermore, vM in land management does not bring in explicit improvements in relevant law enforcement. In 2006, the number of cases that related to the violation of land management law and the area of land that was under illegal usage increased significantly when compared with the previous figures, though VM reform was introduced in that year. ${ }^{36}$ The effectiveness of VM must thus be questioned.

This alerts us to the fact that expectations of environmental vM reform might be too rosy and optimistic, although VM is only promoted within limited fields and geographical ranges. A theoretical critique of VM and its assumed superiority over dual leadership is needed before moving on to assess the current reform plan.

\subsection{A Theoretical Approach}

As models of governance structures, both dual leadership and vM have their advantages and disadvantages. In theory, vM may reduce considerably the principal-agent problem, since it reduces the number of 'gatekeeper agents', in the current environmental VM case, to 31 provincial-level actors who are relatively manageable. ${ }^{37}$ By controlling environmental monitoring and inspection at the provincial scale, local governments' malfeasances, such as the fabrication of monitoring data, can be largely avoided. Since authenticity of monitoring data can be crucial in providing a scientific basis for environmental policy-making, in this sense, the shift of the governing structure can have positive effects on environmental quality and law enforcement. Moreover, vM may facilitate the solution to cross-regional problems, since it enables decision-making at a higher level of authority. This is especially true in tackling environmental problems which have inherent cross-regional features. Compared to a decentralized decision-making structure, the environmental vM reform enables provincial authorities to take the public interest into consideration at a broader scale.

36 Ministry of Land and Resources, 国土资源部通报 2006 年土地违法案件查处情况 (Ministry of Land and Resources circulates the report on investigating and dealing with the cases of land law violations in 2006), (2007) 2 上海土地 (Shanghai Land) 5 .

MERTHA (n 5) 803 . 
In contrast, the most explicit advantage of dual leadership is that it empowers local governments with freedom in mobilizing local resources and making site-specific decisions based on local conditions. This particular structure also brings up the problem of local protectionism and distorted implementation of central laws and policies, as discussed above.

Opponents of VM reform argue that VM may have negative influences on local governments' initiative and creativity; the integrity of local governments' authorities will be jeopardized if too many functions are managed in a vertical manner. ${ }^{38}$ Some scholars contend that the nature of VM is command-andcontrol regulation in a top-down manner and vM per se is against the rule of law. ${ }^{39}$ Based on the assumption of distrust of local governments, environmental VM is inconsistent with the general tendency of environment decentralization, which ushers in openness, participation and self-governance. ${ }^{40}$ In addition to these allegedly 'built-in' problems of $\mathrm{VM}$, limitations of the effectiveness of the VM reform also need to be presented from a micro and practical perspective:

1. Disruption of formal authority relations between local governments and newly centralized agencies by VM.

It may be true that VM can insulate agencies from intervention by local governments, but it can also insulate them from some positive dimensions in their interactions with their former local government hosts.

\section{1) Loss of coordination and sponsorship from local governments}

After VM reform, local governments view former subordinate agencies as: 'these are no longer "my people", so I do not have to take such good care of them in the future. With regard to the flow of budgetary revenues, there is an 'eating in separate kitchens' (分灶吃饭) situation. ${ }^{41}$ By adopting a non-cooperation strategy, local governments can effectively isolate agencies under vM

38 HOU Zhaoxiao, 环境保护垂直管理不能一刀切 (No one-size-fits-all solution to environmental VM reform), (2008) 1 民主与法制 (Democracy and Rule by Law) 28，29; SUN Chang, 地方环境监察监测执法垂直管理体制改革: 利弊争论与改革方向 (Environmental VM reform on monitoring, inspection and law enforcement: debates of pros and cons and directions of reform), (2016) 12 中国行政管理 (Chinese Public Administration) 13 .

39 JIN Liangxin and YANG Haikun, 公法视野下的政府垂直管理改革研究 (Research on VM reforms from the perspective of public law), (2008) 4 江西社会科学 (Jiangxi Social Science) 168.

40 DU Wanping, 对我国环境部门实行垂直管理的思考 (Thoughts on environmental VM in China), (2006) 3 中国行政管理 (Chinese Public Administration) 99.

41 MERTHA (n 5$) 807$. 
in their jurisdictions and prevent them from enforcing law by other methods. Enforcement problems can even be worsened due to the deterioration in relations between centralized agencies and local governments. ${ }^{42}$

The nature of environmental management means that EPBs cannot be completely independent from local governments. Environmental problems are also social and economic problems, the solution to which largely relies on cooperation and sponsorship from local governments. Local EPBs have extra budgetary and personnel necessities for law enforcement work, which are at the will and control of local governments. For example, under the current situation, the point-source discharges of industrial pollutants are generally controlled, leaving the problem of regulating non-point pollution sources and domestic wastes even more intractable and troublesome. The latter particularly requires coordination and investment from local governments.

2) Loss of promotion opportunities at the horizontal level VM reform may bring in a de facto decrease of promotion opportunities, which is a disincentive for officers working in centralized agencies. Before vM reform, officers may have dual channels of promotion: horizontal and vertical. vM cuts off the horizontal line of personnel movement. After VM, it is nearly impossible for officers to gain promotion at local government level. It is questionable whether better performance of officers can be expected while less incentivized in this manner.

2. Weakened supervision of centralized agencies and resulting corruption problems.

VM may breed corruption due to weakened oversight concerning centralized agencies. The core of the supervisory mechanism under VM is to strengthen internal supervision within the same functional system while excluding external intervention. Agencies under VM will be actually be subject to less supervision with the absence of other functional departments within local governments, because superior agencies cannot conduct daily and routine supervision on their subordinated agencies. ${ }^{43}$ 'Without supervisory checks and balances from

$42 \quad$ Ibid., 804.

43 LONG Taijiang and LI Na, 垂直管理模式下权力的配置与制约 (Configuration and control of powers under the model of vM), (2007) 9-6 云南行政学院学报 (Journal of Yunnan College of Public Administration) 54, 57; JIN Liangxin and YANG Haikun (n 39) 167 . 
local governments, corruption from within the centralized system is difficult to avoid'. ${ }^{44}$ There are many empirical examples from previous vM reforms. ${ }^{45}$

3. VM reform below the provincial level may constrain the effectiveness of VM to be realized at a broader scale.

According to Mertha, vM reforms below provincial level in China-in his words 'soft centralization' - 'while successful to some degree, has nevertheless fallen short in its goals and that thus far this transformation remains imperfect and incomplete. ${ }^{46} \mathrm{He}$ argued that provinces, instead of Beijing, become the principal beneficiaries, because they have obtained major powers over allocations of personnel and budgetary resources. He states that such VM reforms 'simply transfer local malfeasance and concentrate it at the provincial level': ${ }^{47}$

The current environmental VM reform also chooses the approach of 'soft centralization'. Though a bundle of powers is to be centralized from the county level to the provincial level, it is still decentralized between the centre and the provinces. In other words, by reconfiguring the institutional structure of environmental management, ie, transforming kuai-based dual leadership to a tiao-based one at municipal level, and subjecting county E PBs to control of municipal EPBS, the current VM reform reserves more power within the functional system of environmental management and enables provincial environmental authorities to place more intensive oversight on anti-environmental behaviour by enterprises and governments at municipal and county levels. However, provincial ЕPBs are still under kuai-based dual leadership. There is still a strong possibility that provincial governments may enforce environmental laws and policies issued by the central government in a lax manner. In other words, local protectionism may move from the municipal and county level to the provincial level and thus result in the phenomenon of 'provincial protectionism'. How to avoid this is still unsolved in the current reform process.

4. Weakening local governments' accountability on environmental protection and colliding with relevant legal provisions.

The Environmental Protection Law and separate environment-related laws ${ }^{48}$ both explicitly prescribe that local governments are responsible and account-

44 MERTHA, $\mathrm{n}_{5}$, above, 804.

45 REN Jianming and LIU Jincheng, 如何看待垂直管理系统的腐败 (How to treat corruption problems in VM systems), (2011) 28 人民论坛 (People's Tribune) 62.

46 MERTHA ( $\left.\mathrm{n}_{5}\right) 791$.

47 Ibid., 803 .

48 For example, Water Pollution Prevention and Control Law of 2008 (Article 4 states that local governments should be responsible for the water environmental quality within their 
able for environmental management. For example, there are around 30 instances in the EPL prescribing the duties and responsibilities of governments and EPBS at county level in environmental management, in which 18 are related to governments at county level. ${ }^{49}$ For example, Article 47 requires county governments to establish public monitoring and early warning mechanisms for environmental pollution and take emergency response measures. Generally, the responsibility of local governments are reflected in four aspects, which are financial investment, supervision and regulation, duty to take active actions in conserving environment and encouragement to enterprises and citizens to take environment-friendly actions.

Opponents of environmental VM argue that VM may take away local governments' responsibility in protecting the environment. It is difficult to hold local governments accountable if they lose control of EPBs that were formerly under their authority.

\subsection{Analysis of the Current VM Reform}

Since environmental vM has been both advocated and opposed for decades, potential problems of a VM structure have been well-discussed and reflected in practice in both environmental management and other fields. As indicated above, the current environmental VM reform consists of a bundle of reform measures, which has to some extent mitigated potential ups and downs of an overturn of the environmental governance structure. Nevertheless, such a piecemeal, albeit progressive approach of reform, can have its side effects as well.

1. Interaction and coordination with local governments

EPBS cannot fulfil their tasks of environmental protection without sponsorship from local governments. On the other hand, local governments also require support of EPBs in realizing the target of environmental protection set in their assessment forms. Pro-active interaction and coordination between environmental organs and their territorial local government is therefore needed.

To realize such interaction, the current VM reform has retained the status of municipal EPBS as a constituent department of municipal governments instead of insulating them under a VM structure. The Guidelines also propose several requirements on the interaction between them:

administrative regions); Air Pollution Prevention and Control Law of 2016 (Article 3 provides similar statement).

These 30 instances can be found in Articles 8-10, 13, 24-29, 33-34, 37, 40, 47, 49-51, 53-54, $60-63$. 
1) Local EPBs should support local governments and CPC committees at corresponding levels in fulfilling their responsibilities of environmental protection, including providing monitoring services to the latter in handling emergent environmental incidents;

2) Municipal EPBs should cooperate with county governments in realizing integrated planning and science-based decision making;

3) Establishment of information-sharing mechanisms: provincial EPBs are in charge of establishing information communication networks and big data fora on environmental monitoring and law enforcement at different levels of government. Local EPBs are required to distribute and report information of EM, EI and law enforcement to local CPC committees, governments and relevant departments at corresponding levels; and

4) Local governments above county level should establish the mechanism of deliberation and coordination (议事协调机制), a platform on which relevant departments may have their voices heard, to solve major environmental problems within their jurisdictions.

2. Accountability mechanisms

With a general principle of local government accountability stipulated in the new EPL, the accountability system on environmental protection is further emphasized and gradually strengthened through a series of policy documents. ${ }^{50}$ Two very important steps were taken in this regard. The first is to include CPC committees in the accountability system, which is termed 'equal accountability of Party and government organizations' (党政同责), in order to avoid buck-passing between Party and governmental organs on environmental matters. The second is the so-called 'dual responsibilities for one position' (一岗双责), which requires that cadres of Party committees and governmental organs should not only be responsible for professional affairs, but also for

50 CCCPC and State Council, 关于加快推进生态文明建设的意见 (Opinions on accelerating the promotion of building ecological civilization), May 2015 ('CPC committees and governments at all levels should be wholly responsible for construction of ecological civilization within their respective jurisdictions'). The terms of 'equal accountability of Party and government organizations' and 'dual responsibilities for one position' were firstly concretized in the Plan of Environmental Protection Supervision (for trial implementation) (环境保护督察方案(试行)) issued by the Reform Group in August 2015. Measures for the Accountability of Party and Government Leaders for Damage to the Ecological Environment (for Trial Implementation) (党政领导干部生态环境损害责任追究办 法(试行)), issued by the General Office of the CCCPC and the General Office of the State Council on 17 August 2015, further emphasized individual liability for Party and governmental leaders. 
actual environmental management and supervision relevant to the position they hold.

The Guidelines explicitly emphasize the accountability of local CPC committees and local governments in guaranteeing environmental quality. Two mechanisms are proposed: the first is assessment and appraisal of target responsibility (目标责任制) for cadres in which ecological environmental quality is set as a major target for such appraisal; and the second is to stipulate accountability for cadres in illegally intervening in EM, law enforcement and investigations into particular environment-related cases.

Besides emphasizing local CPC committees and local government accountability, the Guidelines also propose to strengthen the accountability of relevant departments that shoulder the responsibility of environmental management and supervision. These departments are still under a kuai-based governing structure and may still continue to align their interests with local governments on economic development. Pilot provinces are required to make a list of environmental protection responsibilities (责任清单) for each relevant department and include environmental performance in the list of annual appraisal for these departments.

\section{Intra-agency coordination}

Previously, EM and EI bodies were subordinate to E PBS at corresponding levels. Monitoring and inspection are often compared to the ears and legs of EPBs. ${ }^{51}$ After the functions of monitoring and inspection are stripped from EPBS, a key concern raised by scholars is how EPBs can fulfil their responsibilities with reduced personnel and budget..$^{52}$ The intra-agency relationship between EPBS and relevant EM and EI bodies may encounter a fundamental change after EM and EI functions are centralized. In Wu's words, 'the leadership relationship before the VM reform may be shifted to a brotherhood relationship; or the former leader becomes the one being led. This is what the municipal and county EPBs worry about.53

51 FANG Canfen, 对 “属地管理” 与 “垂直管理” 环保监管改革的探讨 (Discussion on the Environmental Regulation Reform of Territorial Management and Vertical Management), (2016) 1 环境保护(Environmental Protection) 35 .

52 JIANG Mengwei, 环保监察将垂直管理地方环保局角色尴尬 (Vertical management of environmental inspection and the embarrassing role of local EPBs), in 北京商报 (Beijing Business Today), 2 August 2016 <http://news.163.com/16/o802/oo/BTE23C1Cooo14AED.html $>$ accessed 26 December 2016.

YUE Jiachen (n 21). 
To facilitate coordination between EPBs and centralized organs, the Guidelines require that

1) Municipal EM bodies sent by provincial EPBs should attend local EPB meetings and provide support for environmental management and law enforcement at municipal and county levels;

2) Main leaders of municipal EM bodies shall be members of the leading Party members' group of municipal E PBs after consultation with municipal EPBs; and

3) EM bodies at county level should support and cooperate with local environmental law enforcement bodies to realize effective enforcement and quick responses.

To summarize, the current reform plan has taken into consideration potential problems that a shift into VM structure may encounter. As a supplement, general principles and reform measures on cooperation, coordination and accountability are stipulated in the Guidelines. However, practicality and enforceability of them may be limited due to fact that it is a policy document. How the vM reform will be translated into practice and how pilot practices will be escalated still need to be further observed in the long term.

As an ongoing project, the blueprint of environmental vM reform is still under deliberation and the veil of a new governing structure for environmental management in China is still to be lifted. The Guidelines have indicated some significant changes that are taking place or that will occur in the Chinese bureaucracy. This article provides a basic sketch of this ongoing reform and suggests some implications for its continued evolution.

The promotion of VM in the field of environmental management indicates a stronger central commitment to environmental protection, which is decided by long-term practices of central-local relations in the past. Previous vM reforms have been maintained in areas such as financial regulation and commodity management, while environmental VM shows a clear departure from the previous policy focus. The shift from economic VM to environmental VM is a signal of changing central-local relations in this era of environmental consciousness. Decentralization and empowering of local governments have created the socalled 'China Miracle' in its economy. However, due to growing environmental and social problems, the decentralization scenario has been challenged and 
the central government has attempted to realize firmer control over localities. Previously, the centre has attempted to exert its influence and enhance local environmental enforcement by other methods, such as the launch of rounds of $a d$ hoc and prioritized enforcement campaigns. ${ }^{54}$ Moreover, top-down ad hoc supervisory mechanisms are increasingly being used, such as appointment and interview (约谈), and environmental supervision. ${ }^{55}$ The style of campaign enforcement does have a positive effect in curbing local protectionism for as long as it is in place, and top-down mechanisms also help to achieve remarkable outcomes and instant improvement of environmental quality. However, the ad hoc nature of these methods hinders creation of sustainable compliance and routine enforcement. With the call for improvement of environmental law enforcement, structural changes are to be applauded and vM reforms are a typical example of such changes.

But how well may vm lead to better environmental performance? Previous discussions show that the connection between the two is not tenable either from theoretical or empirical perspectives. Neither vM nor dual leadership is a panacea to cure environmental problems and neither of them has inherent superiority over the other. Recognition of the pros and cons of both structures is the premise on which to evaluate the current reform. It is noteworthy that adopting a command-and-control VM structure may sacrifice the creativity and initiative of local governments, but in the field of environmental management, the central government alone cannot solve environmental problems that have a distinctly local feature. Having taken the aforementioned into account, the current VM reform adopts a conservative approach as opposed to a radical one. Several characteristics are summarized below.

First, the term 'vM reform' is not as purely a centralization process as the term might suggest. It is clear that both centralization and decentralization approaches are adopted in the current reform plan. On the one hand, the authority of environmental management is greatly centralized at provincial level. Provincial EPBs obtain the power to nominate local E PBs' leaders, and the power to build a province-scaled monitoring network. By highlighting the function of inspection, ie supervision on governments, provincial EPBs are

54 For discussions of this style of campaign enforcement, see Benjamin VAN ROOIJ et al. (n 24).

55 See generally RAN Ran, “党政同责、一岗双责”：环保 “牙齿” 2.0 中央督政之后, 地方还需什么 (“"Equal accountability of Party and government organizations, "dual responsibilities for one position": the 2.0 version of environmental "teeth"; what else local needs after supervision from the center?”'), in 南方周末 (Southern Weekly), 7 September 2016 <http://www.infzm.com/content/119344> accessed 26 December 2016. 
empowered to supervise local governments' environmental performance and have more mobility in initiating further institutional arrangements, such as the establishment of an environmental ombudsman. On the other hand, a decentralized structure is retained with regard to authority for law enforcement. The dual leadership structure for municipal EPBs is retained and their authority is strengthened by transferring the authority previously held at county level to municipal level. In fact, by distinguishing between new and old inspection, the authority for law enforcement ('old inspection' system) remains largely at local level without being centralized, ie, turning over to higher authorities.

Second, the environmental VM reform is not only a process of soft centralization, a term used by Mertha, but it is also incomplete. The former means it is extended only to the provincial level, and the latter means it only applies to two functions, ie, EM and EI. On the one hand, although soft centralization might be successful in insulating agencies from inappropriate intervention from governments below provincial level, the principal-agent problem still exists, ie, how to effectively control the agents dispersed over $3^{1}$ provinces and avoid 'provincial protectionism', especially considering the intensive centralization of power to provinces shown in the current reform. Furthermore, due to the transboundary nature of environmental problems, in order to realize satisfying enforcement of central environmental laws and policies at a broader scale, jurisdictional limitations need to be unblocked and cross-regional coordination mechanisms need to be strengthened, especially at the provincial level.

On the other hand, the selection of EM and EI for VM reforms cannot guarantee the integrity of environmental management, and results in the need for more coordination efforts. As discussed earlier, the authority relationships among local EPBs, local Party committees and governments, EM and EI bodies, and other relevant departments can become fragmented. Though the Guidelines establish the principle of coordination and propose quite a few mechanisms to facilitate information-sharing and the joining of forces, translation of policy into practice can be a huge challenge to the success of this reform.

Third, the current VM reform, like previous environmental reforms, is dominated by a process of policy-making instead of formal rule-making. ${ }^{56}$ Compared to strict rule-making processes, policies are more flexible and can be changed more easily. This has become a routine trajectory in the reform era of China that the centre uses guidelines and plans to promote significant

$5^{6}$ For discussions of environmental policy-making in China, see generally MA Yun (n24) 169-179. 
organizational reforms within bureaucracies.$^{57}$ Reliance on variable policies in defining the powers and responsibilities of different levels of government may jeopardize the authority of law. The success of environmental vM reform lies in a clear and legally defined distribution of powers and responsibilities between central and lower levels of government, especially among local governments below provincial level. Failure and regression of previous VM reforms in other fields can be an important lesson. Delineation of authorities among different levels of governments via enacting organic laws in this regard is a pressing need.

Some additional legal and policy recommendations are put forward here. First, existing literature has shown the dynamic nature of enforcement problems in China, which are demonstrated by immense regional disparities among coastal areas and central and western China. A situation of 'split enforcement' is prevalent, with 'richer and more urbanized areas having much stronger and more frequent enforcement than inland areas'.58 However, the vM reform is intended to be extended nationwide and the first batch of 12 pilot provinces has been initiated. The geographical choice seems to be based on a cherry-picking process promoted by the willingness and initiative of provincial governments. Questions that are omitted include whether a particular structural reform is universally applicable and desirable across all regions, and whether alternative methods can be more cost effective to overcome local protectionism than vM. An inquiry into regional disparities can be a first step in answering these questions, but is beyond the scope of this article.

Second, organizational change is only a partial solution to enforcement problems. VM may insulate local governments from doing what the centre would not like to see; however, it is prescriptive per se without providing enough incentives for local governments to do what the centre would like to see. An environmental problem is in many ways a development problem. Local governments would not have sufficient incentives without a central solution to problems of poverty and regional disparities in resource allocation. Enhanced financial reforms and provision of equitable economic and ecological services are desired to supplement the organizational overhaul that is required. Moreover, as previously mentioned, the quality and professionalism of

$57 \quad$ SUN Chang $\left(\mathrm{n}_{3} 8\right) 16$.

$5^{8}$ Benjamin VAN ROOIJ, et al., 'Split enforcement: how central local relations affect pollution law enforcement in China', p.1, paper presented at Brown University workshop on Central Local Relations and Environmental Governance on 15-16 May $2015<\mathrm{http}$ ://www .law.nyu.edu/sites/default/files/upload_documents/Split\%2oEnforcement.pdf.> accessed 22 January 2017. 
law enforcement is unsatisfactory due to the complex and unstable availability of enforcement officials at local EPBs. Since enforcement authority is now decentralized to municipal and county levels, capacity building for officials engaged in enforcement at grass-root level should be strengthened, although the setting of personnel quotas can be a thorny issue to tackle, thus hindering a sustainable supply of enforcement resources.

Third, with regard to the potential problem of provincial protectionism, it seems that the centre intends to complement the soft-centralization approach by strengthening ad hoc supervision of provincial Party committees and governments in enforcing environmental law. Moreover, from the recent waves of environmental supervision, there is a tendency to routinize and institutionalize this ad hoc mechanism. The mechanism of environmental inspection on local governments ('new inspection' system) proposed in the Guidelines is a similar power-based, top-down supervisory mechanism. As indicated earlier, these moves might be effective at some time and in some places in the future. However, their effectiveness is rooted in coercion within the bureaucracy rather than conscientious compliance with the law. Furthermore, since five Environmental Supervision Centres, ie, branches of the Ministry of Environment Protection across regions, were already established before the current reform, institutionalization of ad hoc supervision mechanisms will limit the authority of these centres and thus make them only marginally effective. How different forms of central oversight can be coordinated remains under-studied.

Based on the above discussion, this article concludes that as a method to strengthen central oversight on local environmental performance, vM is far from the sole or the most cost-effective method to realize this goal. Neither VM nor dual leadership is a panacea to cure environmental enforcement problems. The argument that vM can result in better environmental performance has not yet been demonstrated, and is for the present, untenable. With a bundle of reform measures, the current VM reform plan is a combination of both centralization and decentralization approaches. However, the design of soft and fragmented centralization may decrease the anticipated effectiveness of VM reform, even though problems of local protectionism may be overcome, as suggested above. It is submitted that, as a partial solution, vM reform needs to be supplemented with robust incentive and accountability mechanisms, and more effective and professional enforcement activities at local levels. 